CZU: 616.31-006-07-08-053.2

https://doi.org/10.52692/1857-0011.2021.2-70.10

\title{
ORAL CAVITY TUMORS IN CHILDREN. DIAGNOSTIC APPROACH
}

\author{
Dănis URSU, medic rezident, Silvia RAILEAN, dr. șt. med., conf. univ., \\ Sergiu CIUPAC, asist. univ., Roman LUPAN, asist. univ., Egor POROSENCOV, asist. univ. \\ Universitatea de Stat de Medicină și Farmacie „Nicolae Testemițanu” \\ e-mail:danis.ursu@usmf.md
}

\begin{abstract}
Summary.
Although the majority of lesions reported in children and adolescents are benign, it should be recognized that oral malignant tumors do occur in children. The incidence of childhood malignancy is greatest in the 1st year of life, with the second peak to be found at 2-3 years of age. Many clinicians do believe that oral cancer is particularly aggressive in young patients, and is associated with poorer survival compared to adults. Numerous early reports of oral cancer in young adults concluded that the disease was more aggressive, and prognosis was poorer than in older adults.

Purpose of this study is to make a literature review on the diagnostic methods of the tumors of oral cavity in children.

Conclusion. Despite the progress in technology and medicine paraclinical examination methods in determining tumors of the oral cavity in children haven't been developed and studied enough, thourder studies have to be done in order to create diagnostic protocols for the pediatric population.
\end{abstract}

Key-words: tumor, oral cavity, children, malignancies.

\section{Rezumat. Tumorile cavității bucale la copii. Abordare de diagnostic.}

Deși majoritatea leziunilor raportate la copii și adolescenți sunt benigne, ar trebui să se recunoască faptul că tumorile maligne orale apar la copii. Incidența malignității copilului este cea mai mare în primul an de viață, cel de-al doilea vârf fiind întâlnit la vârsta de 2-3 ani. Mulți medici cred că cancerul oral este deosebit de agresiv la pacienţii tineri și este asociat cu o supraviețuire mai slabă în comparație cu adulții. Numeroase rapoarte timpurii despre cancerul oral la adulții tineri au concluzionat că boala era mai agresivă și prognosticul era mai slab decât la adulții în vârstă.

Scopul acestui studiu este de a face o revizuire a literaturii cu privire la metodele de diagnostic ale tumorilor cavității bucale la copii.

Concluzie. În ciuda progresului în tehnologia și medicina metodele de examinare paraclinică în determinarea tumorilor cavități bucale la copii nu au fost suficient dezvoltate și studiate, este necesitatea de a efectua studii suplimentare pentru a crea protocoale de diagnosticare pentru populaţia pediatrică.

Cuvinte-cheie: tumoră, cavitate orală, copil, malignitate.

\section{Резюме. Опухоли полости рта у детей. Диагностический подход.}

Хотя большинство поражений, о которых сообщалось у детей и подростков, являются доброкачественными, следует признать, что злокачественные опухоли полости рта действительно встречаются у детей. Заболеваемость злокачественными новообразованиями у детей наиболее высока на 1-м году жизни, а второй пик приходится на 2-3 года. Многие врачи действительно считают, что рак ротовой полости особенно агрессивен у молодых пациентов и связан с более низкой выживаемостью по сравнению со взрослыми. Многочисленные ранние сообщения о раке полости рта у молодых людей показали, что болезнь протекает более агрессивно, а прогноз хуже, чем у пожилых людей.

Целью исследования является обзор литературы по методам диагностики опухолей полости рта у детей.

Заключение. Несмотря на прогресс в технологии и медицине, методы параклинического обследования при определении опухолей ротовой полости у детей не разработаны и недостаточно изучены, необходимы более глубокие исследования для создания диагностических протоколов для педиатрической популяции.

Ключевые слова: опухоль, полость рта, дети, злокачественность.

Introduction. The oral cavity extends from the vermilion border of the lips to the circumvallate papillae of the tongue inferiorly and the junction of the hard and soft palate superiorly. The oral cavity is divided into several anatomical subsites: lip, oral tongue, floor of mouth, buccal mucosa, upper and lower gum, retromolar trigone and hard palate. Despite their proximity, these subsites have distinct anatomical characteristics that need to be taken into account in planning oncologic therapy [7].
The diagnosis of oral pathologic changes is established from the different clinical and radiological features, although the final diagnosis is based on histopathological examination of the lesion. The initial clinical diagnosis must be accurate and should not miss any premalignant or malignant pathologic features.

All oral lesions are divided into three groups, including non-neoplastic lesions, potentially malignant disorders and neoplastic lesions, and are also sub- 
divided into 10 major subcategories: normal tissue, inflammatory and infectious lesions, cystic lesions, adaptive reactions, potentially malignant disorders, autoimmune and metabolic diseases, vascular and hemodynamic anomalies, hamartomatous lesions and congenital alterations, benign neoplasms and malignant neoplasms. Despite the progress made in recent years in the diagnosis and treatment of oral lesions, more clinical data are needed to establish their helpful clinical pattern [9].

Different lesions affect the oral cavity and jaws. They include tumors of odontogenic origin as well as non odontogenic tumor and tumor-like lesions. The frequency or the ratio of these lesions differs depending on the population and geographical location. Other factors, such as age, gender, and localization also define lesions [5].

Tumors and tumor-like growths arising from the odontogenic tissues constitute a heterogenous group of particularly interesting lesions, as they display the various inductive interactions that normally occur among the embryologic components of the developing tooth germ. In humans, tumors of odontogenic tissues are comparatively rare, comprising about $1 \%$ of all jaw tumors. In children and adolescents, neoplastic lesions are often benign and are of mesenchymal origin [8].

Pediatric cancer is diagnosed in $>14,000$ U.S. children per year from the ages of $0-19$ years and is the leading cause of disease-related death among children aged 1-14 years. Although a few risk factors have been conclusively identified, including exposure to high dose radiation and certain genetic syndromes, the etiology underlying most cases remains unknown. Evidence accumulated over several decades suggests positive associations between birth defects and pediatric malignancy. Major anomaly examples include spina bifida, cleft lip palate, and Down Syndrome. Minor anomaly examples include low set ears, epicanthal folds, and simian crease. Although certain genetic syndromes are known to increase pediatric cancer risk (e.g. Down Syndrome and leukemia), other birth defects (including major and minor), independent of known cancer predisposition syndromes, may also be associated with an increased risk. Recent evidence suggests that $8.5 \%$ of children with cancer harbor germline mutations in well-known cancer genes that predispose them to the development of early-onset malignancy [10].

Oral cancer accounts for about $5 \%$ of all malignancies, but occupies an important place in oncological pathology due to certain clinical and evolutionary features, a wide range of morphological types, very diverse treatment methods and different prognosis of each location. In the structure of malignant tumors of the head and neck, cancer of the oral cavity ranks second after laryngeal cancer and is the 8th most common malignancy. The incidence of oral cancer per 100,000 population is 10.5 in men and 1.7 - in women, in men it develops 5-7 times more frequently than in women. People aged 60-70 get sick more often, but it is also found in young people. Approximately $80 \%$ of malignant diseases of the oral cavity are squamous cell carcinomas. Transitional cell carcinomas and lymphoepithelial are a smaller group [1].

Oral cancer has a worldwide incidence of 300,400 cases and is responsible for 145,400 deaths annually. The distribution of oral cancer is approximately $32 \%$ in the buccal mucosa, $22 \%$ in tongue, $11 \%$ in lower lip, $11 \%$ in palate, $8 \%$ in vestibule, $5 \%$ in alveolus, $5 \%$ in floor of the mouth (FOM), and 3\% in the gingiva. Due to the heterogeneous nature of oral cancer, the functional and cosmetic results, and the coexistence of frequent medical comorbidities, treatment options should be evaluated through the multidisciplinary team and evaluated before reaching the final plan. In many countries, surgery remains the first option of treatment for oral cancer. The effects of oral cancer surgery can have a serious impact on a patient's quality of life and can impair appearance and functional characteristics such as speech, mastication, and swallowing [2].

Although the majority of lesions reported in children and adolescents are benign and require minimal intervention, it should be recognized that oral malignant tumors do occur in children. In general, malignant tumors in children and adolescents comprise less than $1 \%$ of all diagnoses. Rhabdomyosarcoma is the most common soft tissue sarcoma of children, adolescents and young adults representing about 3-4\% of all cancers affecting children and $35 \%$ of cases affecting the head and neck region, like Langerhans cell histiocytosis which also has predilection for pediatric population [4].

The incidence of childhood malignancy is greatest in the 1st year of life, with the second peak to be found at 2-3 years of age. Although oral cancer is much less common among the children compared to older adults, according to the recent data approximately 1 in 285 children in the US are diagnosed with the disease before the age of 20 years. While advances in treatment have increased the survival rate for many childhood cancers, the disease is still the second leading cause of death (following accidents) in children ages 5-14 years [2]. Many clinicians do believe that oral cancer is particularly aggressive in young patients, and is associated with poorer survival compared to adults. Numerous early reports of oral 
cancer in young adults concluded that the disease was more aggressive, and prognosis was poorer than in older adults [3].

With contemporary multi-modality therapy, the 5 -year survival rate for pediatric malignancies exceeds $80 \%$. This success has produced 379,000 childhood cancer survivors in the USA. As many as 60 to $90 \%$ of these long-term survivors experience adverse health consequences related to cancer or its treatment, which may not manifest until years after therapy completion. Among treatment-related sequelae, oral and dental complications are common but often overlooked sources of morbidity and impaired health related quality of life [6].

Diagnosis. Most of the clinicians act on an initial clinical diagnosis before embarking on a biopsy to establish a tissue diagnosis. This can be beneficial for beginning treatment immediately if the initial clinical diagnosis is accurate. There is a data deficiency on the assessment of the diagnostic concordance between the clinical and histopathological diagnosis of oral cavity lesions [11].

The clinical TNM stage should be recorded at first encounter and modified as evaluation progresses. The initial workup consists of diagnosis by biopsy. Accessible lesions may be adequately biopsied in the clinic using punch forceps, core needle or fine-needle aspiration. Some patients will require examination under general anesthesia in order to access posteriorly located lesions, or to complete a physical exam limited by pain and trismus. Radiographic imaging is crucial for evaluation of the relation of the tumor to adjacent bone and for assessing regional lymph nodes. CT scan is the study of choice for evaluation of bone and neck nodes, especially early cortical involvement and extracapsular nodal spread. MRI provides complementary information about soft tissue extent and perineural invasion and is helpful for evaluating the extent of medullary bone involvement. Most patients with oral cancer are not at risk for distant metastases and therefore the role of PET scan in initial assessment is debatable. However, a preoperative PET scan may be useful as a baseline if adjuvant treatment is anticipated and a PET scan will be used for radiation therapy planning (though this is undertaken differently from a ,diagnostic" PET scan) [7].

Clear positive associations exist between birth disorders and pediatric cancer with evidence for increased risks for specific cancer/birth disorder type combinations. With advances in mutation detection through next generation sequencing technologies it may be possible to identify genetic causes underlying some of these cases, which will provide insight into overlaps between genes impacting both development and ma- lignancy and provide a basis for identification of high risk populations among children with congenital abnormalities [10]. Next-generation sequencing (NGS) technology has expanded in the last decades with significant improvements in the reliability, sequencing chemistry, pipeline analysis, data interpretation and costs. A number of clinical applications are reviewed, i.e., mutation detection in inherited cancer syndromes based on DNA-sequencing, detection of spliceogenic variants based on RNA-sequencing, DNA-sequencing to identify risk modifiers and application for pre-implantation genetic diagnosis, cancer somatic mutation analysis, pharmacogenetics and liquid biopsy [17].

\section{Fine needle aspiration biopsy}

In the oral cavity, the fine needle aspiration biopsy method is rarely used. The most common masses biopsied in this manner are odontogenic tumors, intraosseous lesions, minor salivary gland tumors, sublingual salivary glands and other oral regions. However, some reports have described the relevance of FNAB for the diagnosis of oral cavity lesions and oropharyngeal lesions. The most commonly described advantages of the FNAB method are the preoperative diagnoses of lesions, clinical follow-up, the ability to avoid unnecessary damage to crucial structures of the oral cavity, more comfort for the patient and a low risk of infection and tissue damage. The most commonly reported disadvantages are the fact that there is little space to perform the backward and forward movement necessary to complete the procedure, and the difficulty involved in fixing the lesion. The sensitivity of FNAB in intraoral lesions may vary from $80 \%$ to $100 \%$; specificity varies from $80 \%$ to $100 \%$ and the accuracy varies from $60 \%$ to $100 \%$. The false positive rate has been reported to vary from 0 to $3 \%$ and the false negative rate from 0 to $20 \%$. The most common diagnostic problem reported during the use of FNAB in the oral cavity is an insufficient amount of material collected for analysis due to the difficulty of applying the technique in this region [12]. Fine-needle aspiration cytology shows high accuracy in the diagnosis of pediatric salivary gland tumors, with diagnostic sensitivity and specificity similar to those reported for adult patients [16].

Computer-assisted analysis of a brush or/and scalpel biopsy is a highly sensitive and specific, noninvasive test in the evaluation of all oral lesions without an etiology. The test is especially beneficial when used on lesions that appear clinically benign for identifying early stage cancers and dysplasias the lesions for which therapy is most effective. As an adjunct to oral cancer examination, its use has the potential to reduce the poor mortality rate associated with oral malignancies [18]. 
18F-FDG PET/CT (Positron Emission Tomography/computed tomography)

Compared with PET alone, an open-mouth 18F-FDG PET/CT scan in patients with oral cavity carcinomas can improve the tumor localization, evaluation of tumor extent, and detection of tumor involvement of adjacent structures. Mid-morning scheduling of the examination, relaxation of muscles before the radiotracer administration, and a wait time with the patient upright may reduce the equivocal physiologic uptake generally frequent in this area. Finally, this imaging protocol seems to allow a better localization of potentially synchronous tumors [13].

The analysis of saliva as a diagnostic approach for systemic diseases was proposed just two decades ago, but great interest in the field has emerged recently because of its revolutionary potential as a liquid biopsy. Saliva is called the mirror of the body, as it is considered an ultra-filtrate of the blood and because its composition changes under different pathological conditions. Multiple molecules isolated from saliva can be used as cancer biomarkers for diagnosis, prognosis, drug monitoring and pharmacogenetic studies. With all of the above, saliva represents a fluid enriched with tumour markers in patients with cancer remote/ distant to the oral cavity. However, further research is needed in the different "omics" fields to consider saliva a liquid biopsy for a routine clinical usage. Regarding challenges in the field, a major limitation in saliva research is identifying specific disease biomarkers with high sensitivity and specificity [14].

With advances in molecular biology, viral driven malignancies have gained recognition and tumors have become more molecularly defined. Accordingly, diagnostic requirements in head and neck pathology have become more refined. Molecular diagnostic modalities, in particular ISH, have become the cornerstone of diagnosis in tumors with challenging morphology. ISH is an important adjunct to the diagnosis of HPV and EBV driven malignancies. Fur-

\section{Bibliography}

1. Protocolul clinic naţional „Cancerul cavității bucale”, Chișinău, 2012.

2. Clinical and Experimental Otorhinolaryngology Vol. 12, No. 2: 107-144, May 2019.

3. Wani V., Kulkarni A., Pustake B., Takate V., Wani P., Sondhi J.S. Prevalence, complications and dental management of the oral cancer in the pediatric patients. J Can Res Ther 2018;14:1407-11.

4. Prosdócimo M.L., Agostini M., Romañach M.J., de Andrade BAB. A retrospective analysis of oral and maxillofacial pathology in a pediatric population from Rio de Janeiro - Brazil over a 75-year period. Med Oral Patol Oral Cir Bucal. 2018 Sep 1;23 (5):e511-7. thermore, FISH is helpful in establishing diagnosis in a variety of salivary gland neoplasms including pleomorphic adenoma, mucoepidermoid carcinoma, secretory carcinoma, hyalinizing clear cell carcinoma and adenoid cystic carcinoma. Soft tissue tumors including small round blue cell neoplasms and spindle cell neoplasms are difficult due to morphological overlap between different entities and FISH is often essential in the diagnosis of Ewing sarcoma, rhabdomyosarcoma, synovial sarcoma, biphenotypic sinonasal sarcoma, dermatofibrosarcoma protuberans, nodular fasciitis and inflammatory myofibroblastic tumor. The use of FISH is also important in separating high-grade $\mathrm{B}$-cell lymphomas with $M Y C$ and $B C L 2$ or $B C L 6$ translocations from DLBCL. FISH plays a critical role in the diagnosis of newer entities such as HPV-related carcinoma with adenoid cystic like features and adamantinoma-like EFT while we still gain experience and familiarity with these evolving concepts [15].

\section{Conclusion}

The diagnosis of oral pathologic changes is established from the different clinical and radiological features, although the final diagnosis is based on histopathological examination of the lesion. The initial clinical diagnosis must be accurate and should not miss any premalignant or malignant pathologic features. Although the majority of lesions reported in children and adolescents are benign, it should be recognized that oral malignant tumors do occur in children. Clinical examination of pediatric patients can be found as a difficult task to achieve due to age particularities, clinical examination under general anesthesia should be evaluated in such situations. Despite the progress in technology and medicine paraclinical examination methods in determining tumors of the oral cavity in children haven't been developed and studied enough, thourder studies have to be done in order to create diagnostic protocols for the pediatric population.

5. Kilinc A., Saruhan N., Gundogdu B., Yalcin E., Ertas U., Urvasizoglu G. Benign tumors and tumor-like lesions of the oral cavity and jaws: An analysis of 709 cases. Niger J Clin Pract 2017;20:1448-54.

6. Effinger K.E., Migliorati C.A., Hudson M.M., McMullen K.P., Kaste S.C., Ruble K., Guilcher G.M., Shah A.J., Castellino S.M. Oral and dental late effects in survivors of childhood cancer: a Children's Oncology Group report. Support Care Cancer. 2014 Jul;22(7):200919. doi: 10.1007/s00520-014-2260-x. Epub 2014 Apr 30. PMID: 24781353; PMCID: PMC4118932.

7. Montero P.H., Patel S.G. Cancer of the oral cavity. Surg Oncol Clin N Am. 2015 Jul; 24(3):491-508. doi: 
10.1016/j.soc.2015.03.006. Epub 2015 Apr 15. PMID: 25979396; PMCID: PMC5018209.

8. Ajayi, O.F., Ladeinde, A.L., Adeyemo, W.L. et al. Odontogenic tumors in Nigerian children and adolescents- $a$ retrospective study of 92 cases. World J Surg Onc 2, 39 (2004).

9. Błochowiak K., Farynowska J., Sokalski J., Wyganowska-Świątkowska M., Witmanowski H. Benign tumors and tumour-like lesions in the oral cavity: a retrospective analysis. Advances in Dermatology and Allergology/Postępy Dermatologii i Alergologii. 2019;36(6):744751. doi:10.5114/ada.2018.78805.

10. Johnson K.J., Lee J.M., Ahsan K., Padda H., Feng Q., Partap S. et al. (2017) Pediatric cancer risk in association with birth defects: A systematic review. PLoS ONE 12(7): e0181246.

11. Tatli, Ufuk \& Erdoğan, Ozgür \& Uğuz, Aysun \& Ustün, Yakup \& Sertdemir, Yasar \& Damlar, Ibrahim. (2013). Diagnostic Concordance Characteristics of Oral Cavity Lesions. The Scientific World Journal. 2013. 785929. 10.1155/2013/785929.

12. Santos, Ana Paula Candido dos, Sugaya, Norberto Nobuo, Pinto Junior, Décio dos Santos, \& Lemos Junior, Celso Augusto. (2011). Fine needle aspiration biopsy in the oral cavity and head and neck region. Brazilian Oral Research, 25(2), 186-191

13. Cistaro A., Palandri S., Balsamo V., Migliaretti G., Pentenero M., Testa C., Cusmà S., Ceraudo F., Gandolfo S., Ficola U. Assessment of a new 18F-FDG PET/CT protocol in the staging of oral cavity carcinomas. J Nucl Med Tech- nol. 2011 Mar;39(1):7-13. doi: 10.2967/jnmt.110.074906. Epub 2011 Feb 14. PMID: 21321252.

14. Rapado-González Ó., Majem B., Muinelo-Romay L., López-López R., Suarez Cunqueiro M.M. Cancer Salivary Biomarkers for Tumors Distant to the Oral Cavity. Int J Mol Sci. 2016 Sep 12;17(9):1531. doi: 10.3390/ ijms17091531. PMID: 27626410; PMCID: PMC5037806.

15. Luk, P.P., Selinger, C.I., Cooper, W.A. et al. Clinical Utility of In Situ Hybridization Assays in Head and Neck Neoplasms. Head and Neck Pathol 13, 397-414 (2019).

16. RonchiA., Montella M.,Zito MarinoF., Panarese I., Pagliuca F., Colella G., Franco R., Cozzolino I.. Diagnostic accuracy of FNA cytology for diagnosis of salivary gland tumors in pediatric patients. Cancer Cytopathol. 2019 Aug;127(8):529-538. doi: 10.1002/cncy.22162. Epub 2019 Jul 10. PMID: 31291059.

17. Kamps R., Brandão R.D., Bosch B.J., Paulussen A.D., Xanthoulea S., Blok M.J., Romano A. Next-Generation Sequencing in Oncology: Genetic Diagnosis, Risk Prediction and Cancer Classification. Int J Mol Sci. 2017 Jan 31;18(2):308. doi: 10.3390/ijms18020308. PMID: 28146134; PMCID: PMC5343844.

18. Mehrotra R., Mishra S., Singh M., Singh M. The efficacy of oral brush biopsy with computer-assisted analysis in identifying precancerous and cancerous lesions. Head Neck Oncol. 2011 Aug 24;3:39. doi: 10.1186/1758-3284-3-39. PMID: 21864339; PMCID: PMC3177776.

УДК: 616.22-006-089

https://doi.org/10.52692/1857-0011.2021.2-70.11

\title{
РОЛЬ ХИРУРГИЧЕСКОГО МЕТОДА В КОМПЛЕКСНОМ ЛЕЧЕНИИ РАКА ГОРТАНИ
}

\author{
Кристина АЛБУЛ, Георгий ЦЫБЫРНЭ, акад., др. хаб. мед. наук, проф., \\ Николай ГОРШКОВ, Андрей ЦЫБЫРНЭ, др. мед. наук \\ e-mail:gh_tsibirna@yahoo.com
}

Государственная программа 2020-2023 «Современная индивидуальная хирургия в комплексном лечении опухолей y demeй» № 20.80009.8007.06.

\section{Резюме.}

В результате изучения динамики заболеваемости рака гортани в Республике Молдова, в период с 1980 по 2020 гг. было установлено, что ежегодно, злокачественной опухолью гортани, в среднем заболевает около 120 пациентов. На протяжении 40 лет было выявлено 874 больных, из них больше $80 \%$ поступило на лечение в 3-4 стадии заболевания. В данной статье были изучены результаты хирургического лечения 258 больных с местно-распространенной формой рака гортани. Исходя из особенностей распространения рака гортани на соседние органы и ткани, дали нам основание выделить пять основных видов хирургического вмешательства: верхняя, нижняя, передняя, задняя и боковая. Оправданность этих операций доказывается продолжительностью жизни больного, которая составляет 53,6\%.

Ключевые слова: рак гортани, статистика, хирургическое лечение, комбинированное лечение. 